University of Nebraska - Lincoln

DigitalCommons@University of Nebraska - Lincoln

Papers in the Earth and Atmospheric Sciences

Earth and Atmospheric Sciences, Department

2016

\title{
Accommodation of penetrative strain during deformation above a ductile décollement
}

Bailey A. Lathrop

Caroline M. Burberry

Follow this and additional works at: https://digitalcommons.unl.edu/geosciencefacpub

Part of the Earth Sciences Commons

This Article is brought to you for free and open access by the Earth and Atmospheric Sciences, Department of at DigitalCommons@University of Nebraska - Lincoln. It has been accepted for inclusion in Papers in the Earth and Atmospheric Sciences by an authorized administrator of DigitalCommons@University of Nebraska - Lincoln. 


\title{
Accommodation of penetrative strain during deformation above a ductile décollement
}

\author{
Bailey A. Lathrop* and Caroline M. Burberry* \\ DEPARTMENT OF EARTH AND ATMOSPHERIC SCIENCES, UNIVERSITY OF NEBRASKA-LINCOLN, 214 BESSEY HALL, LINCOLN, NEBRASKA 68588, USA
}

\section{ABSTRACT}

The accommodation of shortening by penetrative strain is widely considered as an important process during contraction, but the distribution and magnitude of penetrative strain in a contractional system with a ductile décollement are not well understood. Penetrative strain constitutes the proportion of the total shortening across an orogen that is not accommodated by the development of macroscale structures, such as folds and thrusts. In order to create a framework for understanding penetrative strain in a brittle system above a ductile décollement, eight analog models, each with the same initial configuration, were shortened to different amounts in a deformation apparatus. Models consisted of a silicon polymer base layer overlain by three fine-grained sand layers. A grid was imprinted on the surface to track penetrative strain during shortening. As the model was shortened, a series of box fold structures developed, with a zone of penetrative strain in the foreland. Penetrative strain in the foreland decreases away from the fold belt. Restoration of the model layers to the horizontal indicates that penetrative strain accounts for $90.5 \%-30.8 \%$ of total shortening in a brittle system with a ductile décollement, compared to $45.2 \%-3.6 \%$ within a totally brittle system. Analog model geometries were consistent with the deformation styles observed in salt-floored systems, such as the Swiss Jura. Penetrative strain has not been accounted for in previous studies of salt-floored regions and estimates of this type could help resolve concerns of missing shortening highlighted by global positioning system data.

\section{INTRODUCTION}

Penetrative strain is defined as the amount of the total shortening that is not taken up by the development of macroscale structures such as folds and thrusts (Burberry, 2015). Penetrative strain can occur as layer-parallel strain in the early stages of deformation (Groshong, 1975; Dean et al., 1988; Weil and Yonkee, 2009), or as a second subhorizontal strain event as increased stress is accommodated by such strain during the deformation sequence (Gray and Mitra, 1993). Many strain fabrics are accommodated by twinning, dislocation creep, and dislocation glide. In contrast, penetrative strain can be accommodated by pore collapse, rigid clast rotation, and clast repacking (Meere et al., 2008, 2016), as well as by intragranular processes such as stylolitizitation, cleavage, or grain impingement (Groshong, 1975; Engelder and Engelder, 1977; Henderson et al., 1986; Onasch, 1993; Tavarnelli, 1997). Slip on minor fault sets may also accommodate penetrative strain on a larger scale, across

\footnotetext{
*Emails: balathrop@icloud.com; cburberry2@unl
}

a regional cross section (Wojtal, 1989; Hogan and Dunne, 2001).

Thin-skinned contraction over an evaporite décollement has several distinctive features that differentiate it from a contraction of a purely brittle system. Halite, the dominant component of brining-upward evaporite sequences (Popov, 2000) is weak and tends to act as a detachment in both extensional and compressional tectonic activity, allowing the accommodation of greater décollement slip (Davis and Engelder, 1985; Jackson and Talbot, 1991; Cotton and Koyi, 2000). Thrust belts overlying evaporites are likely to have (1) a much wider deformation zone, (2) a lower taper, (3) wide synclinal structures and tight, salt-cored anticlines, and (4) variable vergence of structures (Davis and Engelder, 1985; Jaumé and Lillie, 1988; Pennock et al., 1989; Letouzey et al., 1995; Cotton and Koyi, 2000; Bahroudi and Koyi, 2003; Bonini, 2003; Hudec and Jackson, 2007) relative to a belt overlying a frictional detachment. Where the evaporite layer is relatively thin, box-shaped folds develop, with small salt bodies in the cores, but where the evaporite layer is thicker, anticlines cored by salt pillows develop (Costa and Venderville, 2002). Under extensive shortening, salt bodies may eventually form surface-piercing diapirs (Costa and Venderville, 2002). In many settings, such fold-thrust belts also overprint previous extensional structures (e.g., the Salt Ranges, Pakistan; Pennock et al., 1989). This leads to nucleation of thrust faults above the previous extensional structures, facilitated by the mobile salt layer (e.g., the Subalpine Molasse basin; Burkhard and Sommaruga, 1998).

Sandbox analog models of brittle thrust systems with a silicon polymer base, simulating deformation above evaporite horizons, have shown the same four characteristics as listed here (Cotton and Koyi, 2000; Costa and Venderville, 2002; Bahroudi and Koyi, 2003; Bonini, 2003; Brun and Fort, 2011; Konstantinovskaya and Malavieille, 2011; Qayyum et al., 2015). The high viscosity of the silicon allows for a wider thrust zone and the spacing of the thrusts is much greater than that of those developed in a frictional-based system. Dooley et al. (2005) showed that major salt diapirs form above inverted normal faults, similar to the situation developed in the Subalpine Molasse basin (Burkhard and Sommaruga, 1998).

Despite statements from authors, including Epard and Groshong (1995), on the changes in 
bed length that arise if penetrative strain is not considered, and the body of work on penetrative strain measurement (Epard and Groshong, 1995), typical cross-section restorations ignore this component of deformation (Woodward et al., 1986). The calculation of penetrative strain may be significant in finding the discrepancy between observed shortening rates and inferred shortening rates across orogens. Hessami et al. (2006) conducted a study across the Arabian Zagros fold belt using global positioning system (GPS) data that showed a discrepancy in shortening rates compared to those generated from cross sections. The GPS data indicate a shortening rate of $13-22 \mathrm{~mm} \mathrm{a}^{-1}$ in the present day, whereas the post-Miocene shortening rate was calculated by Agard et al. (2005), incorporating data from McQuarrie (2004), as 5-9.3 mm $\mathrm{a}^{-1}$. Possible additional explanations for missing shortening across an orogen include strike-slip faulting with extrusion of material (Guillot et al., 2003) and microplates deforming the system and causing strain partitioning between several boundaries (Nilforoushan et al., 2003; Vernant et al., 2010; Mouthereau et al., 2012). Underthrusting and the detachment of crustal material on the downgoing plate (Zhao et al., 1993) and extension along the strike of the orogen (Hessami et al., 2006) can also account for some of the discrepancy. In short, geologic models that measure shortening by only folding and thrusting are generally considered to be oversimplified.

In order to incorporate penetrative strain into deformation restorations, one must have an understanding of how penetrative strain affects different regions. The amount of penetrative strain is variable in time and space. Penetrative strain is cited as an early process, occurring before folding or faulting (Geiser and Engelder, 1983; Henderson et al., 1986; Dean et al., 1988; Gray and Mitra, 1993). The amount of penetrative strain varies with location in the orogen (Fischer and Coward, 1982; Mitra, 1994; Weil and Yonkee, 2009; Masini et al., 2010). Koyi (1995) found that penetrative strain magnitude varies with depth in a sedimentary system using analog models, a result duplicated in Burberry (2015). The documented amount of penetrative strain in natural situations ranges from $2 \%$ to $23 \%$ depending on the lithology, method of penetrative strain accommodation, and location within the orogen (Wiltschko et al., 1985; Sans et al., 2003; Koyi et al., 2004). In an analog modeling study (Burberry, 2015) forming the most direct comparison to this study, it was found that in a brittle system, (1) the proportion of the total shortening accommodated by penetrative strain varies with time; (2) penetrative strain increases with depth; (3) penetrative strain is highest before the initiation of a new thrust, and after a new thrust forms, penetrative strain decreases abruptly; and (4) penetrative strain decreases exponentially from the most foreland thrust toward the foreland. These results are consistent with findings from Mitra (1994), Koyi (1995), and Weil and Yonkee (2009).

Existing research on the accommodation of penetrative strain in brittle units overlying a ductile décollement shows that, in an example from the Pyrenees, $16 \%-23 \%$ shortening has been accommodated by penetrative strain in those brittle units, compared to $\sim 5 \%$ from folding and thrusting (Sans et al., 2003). This is interpreted to show a clear decoupling of the sedimentary layers above the Cardona salt, and little variation in internal distortion over a wide area (Sans et al., 2003). In analog models of the same region, Koyi et al. (2004) found that layers overlying a ductile substrate accommodated less penetrative strain than layers shortening over a frictional detachment. This was attributed to the tendency of layers overlying a salt décollement to fold, rather than develop imbricate faults. In contrast to these studies, focusing on evaluating a specific area, we aim to provide a framework for how penetrative strain varies spatially and temporally throughout a deformation sequence. We compare our results to those obtained for similar experiments in a fully brittle system (Burberry, 2015). Our models are stylized and not intended to be a direct representation of any one natural setting. The experimental results document the variation in penetrative strain with depth in the stratigraphic section, and with an increase in total shortening. We document the presence and width of a strained foreland, developing and persisting throughout the deformation sequence.

\section{MATERIALS AND METHODS}

This study was designed after a penetrative strain study (Burberry, 2015). The behavior of a brittle sand pack over a ductile detachment was modeled using an analog box setup consisting of a box with one moving wall driven by a stepper motor and two cameras set up and leveled to photograph the top and side views of the models. The model apparatus is $48 \mathrm{~cm}$ wide and had an initial starting length of $64 \mathrm{~cm}$ in these experiments (Fig. 1A). The box base, moving wall, and fixed wall were made of waterproofed plywood, and the sides were made of glass. The sides of the apparatus were not lubricated, as the model was wide enough to obtain results from the center of the box that were free from edge effects. The standard rule for avoiding edge effects is to use a section of the model greater than or equal to the height of the sedimentary wedge (Burberry, 2015). Representative slices were sliced between 8 and $40 \mathrm{~cm}$ across the apparatus, leaving a margin of $8 \mathrm{~cm}$ on each side that was affected by edge effects, and $32 \mathrm{~cm}$ that can be used for analysis. The motor that powers the moving wall is capable of driving the wall
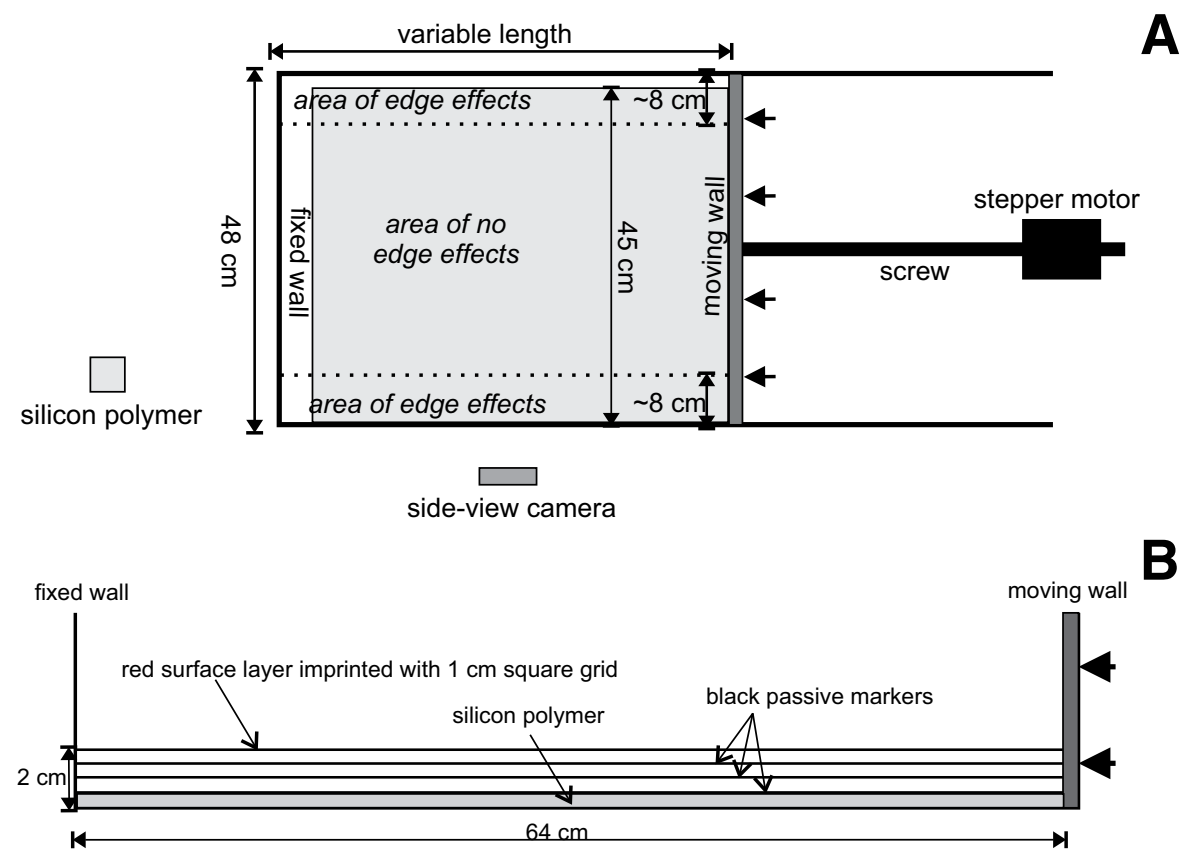

Figure 1. (A) Plan-view diagram of the apparatus showing where the silicon polymer was placed, the area where edge effects are present, and the area used for analysis in the center of the model. (B) Side-view diagram of the initial model set-up used in this study, with dimensions. Both parts of the figure are modified after Burberry (2015). 
at various constant rates between 4 and $8 \mathrm{~mm} / \mathrm{h}$. Typically, models are run at a constant speed of $8 \mathrm{~mm} / \mathrm{h}$, but due to the nature of the silicon base layer, the velocity of the moving wall varied between 6 and $8 \mathrm{~mm} / \mathrm{h}$, depending on the buildup of the silicon layer. The apparatus was cleaned and allowed to dry between experiments.

Eight analog models were run to investigate the amount of penetrative strain accommodated by a contractional system with a salt detachment over multiple increments of deformation. Each model had the same setup. A 5-mm-thick and $58 \mathrm{~cm}$ by $45 \mathrm{~cm}$ silicon polymer was laid in the apparatus overnight to allow it to spread evenly. Three layers of fine-grained quartz sand were poured over the silicon and smoothed with a scraper, but not compacted (Fig. 1B). The sand was sifted using a \#35 standard test sieve before use to remove any sand with a grain size larger than $0.5 \mathrm{~mm}$. Very thin marker layers of black dyed fine-grained sand were used to separate the three layers and to track deformation. A grid was imprinted on the top surface of each model to track strain patterns in the foreland throughout each model run. The initial set up was the same for every model and each had the same starting length $(640 \mathrm{~mm})$. Models $1-8$ were shortened by different amounts. Model 1 was shortened the least and model 8 was shortened the most (Table 1).

This series of models is not scaled to match any specific natural situation. It was intended to be a simple system, tracking penetrative strain timing, magnitude, and distribution of a brittle compressive system with a salt detachment to create models potentially applicable to multiple settings (e.g., the Faltenjura, Switzerland). Rounded, fine-grained quartz sand is used to represent brittle sedimentary units in analog models scaled to specific natural situations (Moretti and Callot, 2012). The sand shows little elastic deformation in analog experiments.

TABLE 1. LIST OF ALL MODELS IN THIS STUDY AND THEIR RESPECTIVE SHORTENINGS

\begin{tabular}{ccc}
\hline Model & $\begin{array}{c}\text { Displacement of } \\
\text { back wall }(\mathrm{mm})\end{array}$ & $\begin{array}{c}\text { Shortening } \\
(\%)\end{array}$ \\
\hline 1 & 12.8 & 2.9 \\
2 & 32 & 7.3 \\
3 & 44.8 & 10.2 \\
4 & 64 & 14.5 \\
5 & 96 & 21.8 \\
6 & 108.8 & 24.7 \\
7 & 128 & 29.1 \\
8 & 160 & 36.4 \\
\hline
\end{tabular}

Note: Shortening is shown as a displacement and \% total shortening with respect to the constant pin line placed $200 \mathrm{~mm}$ from the original position of the back wall; 440 was the original length for calculation purposes.
Both the fine-grained sand layers and dyed finegrained sand marker layers are mechanically similar, according to measurements in Burberry (2015), following the methodology of Krantz (1991). The fine-grained sand was measured in a laboratory using a modified Hubbert apparatus (Hubbert, 1937) to have with an internal friction coefficient of 0.59 and an angle of internal friction of $30.5^{\circ}$. The sand size and model thickness results in a 150-mm-thick sand pack composed of $\sim 300$ grains of sand finer than 0.5 $\mathrm{mm}$. Scaling up to a reasonable situation where $1 \mathrm{~cm}$ in the model depth equals $1 \mathrm{~km}$ in nature leaves the sand grains representing clasts of 5 $\mathrm{m}$ length in nature. This scaling relationship is a simplification in the model and is one of the reasons that the model results are taken to be underestimates of the natural situation, as discussed in the following.

A silicon polymer, Xiameter RBG-0901, was used to model the behavior of a salt detachment layer. Xiameter RBG-0901 is produced by Dow Corning and is a Newtonian viscous material. It has a viscosity of $\sim 2 * 10^{4} \mathrm{~Pa}$ s at room temperature, a density of $0.97 \mathrm{~g} \mathrm{~cm}^{-3}$, and strain rates of $10^{-5}-10^{-3} \mathrm{~s}^{-1}$, representing rock salt (Jackson and Talbot, 1991; Warsitzka et al., 2013). Similar to rock salt, the silicon is incompressible. The silicon can accurately simulate salt in a natural setting, such as the Faltenjura, Switzerland (Bonini, 2003; Warsitzka et al., 2013).

Throughout the experiment, photographs were taken at the side view and overhead at the initial length, every $1 \%$ shortening, and at the final length. Top surface photographs were used to track the appearance of thrust sheets and to track penetrative strain throughout different stages of shortening. They were used to track the amount of strain in the foreland zone, ahead of the frontal thrust sheet, and measure the width of the foreland zone. Strain in the foreland zone was measured by digitally fitting unit circles to photographs of the undeformed grid overlaying the model in front of the foreland and comparing this to strain ellipses in photographs of the deformed foreland grid. A plan-view diagram of a model with a grid and strain ellipses, indicating the calculation methods, can be found in Burberry (2015). The amount of strain $e$ was calculated on the deformed grid using the standard formula $e=\left(l-l_{0}\right) /\left(l_{0}\right)$ where $l$ is the deformed length of the grid square and $l_{0}$ is the original length of the grid square, to measure the strain within the deformed foreland zone.

Once each model had reached its desired shortening (Table 1), a sand pack was added to preserve its topography, the model was wetted with a soap solution, and sliced into cross sections. The sand was wetted with a low-waterpressure garden sprayer that did not affect the configuration of the sand grains. Cross sections were sliced with a flat-bladed knife. With some skill, clean cuts could be made without distorting the structure of the models. Cuts were made every $10 \mathrm{~cm}$ across the model and photographs were taken at every cross section. Representative cross sections of each model were digitized using MOVE (Midland Valley Exploration Ltd. software; http://www.mve.com/software) and the deformation of the fold thrust belt was restored to the original flat layer configuration using unfolding and unfaulting algorithms. Thrusts were restored manually by reuniting the hanging-wall and footwall cutoffs of the marker layers, where relevant, and then removing the associated folding using an unfolding algorithm that maintains line length. This generated a restored length for each marker layer. The restored length compared to the deformed length gives the tectonic shortening in millimeters. The amount of shortening due to penetrative strain can be found by subtracting the tectonic shortening in millimeters from the imposed, known total shortening. An illustration of the restoration process can be found in Burberry (2015, fig. 4 therein). Given the nature of the input section, with parameters such as stratigraphic thickness, depth to décollement, and presence or absence of erosion being well constrained (Judge and Allmendinger, 2011), the expected error in the line-length restoration is small and discrepancies are reasonably expected to be due to penetrative strain.

An assumption was made that only plane strain was acting on the models, which is reasonable because the model apparatus and setup did not allow for significant out-of-plane movement in the central portion of the model, outside of the area affected by edge effects that was excluded from the study. The amount of shortening from faulting and folding was calculated from the restored cross sections. The difference between the calculated tectonic shortening and the known total shortening represents shortening as a result of penetrative strain. Volume loss by sand and silicon escape was negligible in these models as the moving wall was fit tightly to the sides and base of the apparatus, so the discrepancy between total shortening and calculated tectonic shortening can be assumed to be from penetrative strain.

In these models, penetrative strain is occurring in the brittle sand pack only. The penetrative strain portion of deformation was a result of the compaction of grains, grain rotation, and removal of pore space generated during model setup. This compaction introduced strain hardening into each thrust sheet, indicating that the region with the most penetrative strain accommodation will be the next area to 
change during deformation. Johnson (1980) showed the mathematics behind strain hardening in sedimentary or upper crustal rocks in different situations, that is, with frictional contacts between layers, or with ductile contacts with layers. Johnson (1980) demonstrated that faulting is expected in the former case, and folding in the latter; all of his mathematical expressions account for an element of strain hardening in the units, thus the models are representing a phenomenon expected in nature. Most penetrative strain exists in, below, or in front of the active thrust sheet, implying that the maximum zone of penetrative strain moves toward the foreland. This experiment has some simplifications. It is important to note that there are many mechanisms by which penetrative strain may be accommodated in brittle systems in nature such as twinning and grain impingement, as well as clast rotation and loss of pore space. This study is only addressing one mechanism of penetrative strain, compaction due to loss of pore space, thus calculations from this study are underestimations of the true amount of penetrative strain. In addition, in nature, penetrative strain can be categorized into early, more typical layer-parallel strain (as seen in our models), or a later stage parallel strain, which is not necessarily parallel to strain due to layer rotation (Geiser and Engelder, 1983; Couzens et al., 1993; Gray and Mitra, 1993). These additional penetrative strain events do not appear in these models because the sand pack is isotropic. However, these models are considered to provide preliminary constraints on penetrative strain distribution during the compression of a brittle sedimentary succession over an evaporite décollement.

\section{RESULTS}

Each model developed a series of structures, which can be summarized as low-amplitude box folds, high-amplitude box folds, forelandverging thrusts, and hinterland-verging thrusts (Fig. 2). Generally, anticlines were narrower than the intervening synclines. Synclinal structures caused thinning of the silicon and restricted silicon flow and basal drag restricted its forward movement, resulting in layer thickening at the back of the thrust zone. Silicon thickened under the deforming zone and later accumulated in the cores of the high-amplitude box folds (Fig. 2B). There was also minor silicon accumulation in the cores of the lower amplitude box folds (Fig. 2A). In some cases, silicon was observed being incorporated into the thrust planes of hinterlandand foreland-verging structures (Figs. 2C, 2D). Figures 3 and 4 show photographs and line drawings of representative cross-section slices from successive models. Each model underwent increased amounts of shortening between $2.9 \%$ and $36.4 \%$ total shortening, so the amount of deformation and number of thrusts and folds increase with each successive model. Shortening amounts in this study are calculated with an initial length of $44 \mathrm{~cm}$ for each model; 20 $\mathrm{cm}$ that was not deformed in any model was removed from the calculations of every model, allowing for more realistic shortening percentages for comparison to natural examples. The $20 \mathrm{~cm}$ removed is not shown in Figures 3 and 4.

Model 1 (Fig. 3A) was shortened $1.28 \mathrm{~cm}$ to a total shortening of $2.9 \%$. Very little deformation occurred during this short period of contraction. An anticline (feature i) began to form. The width of the fold belt was $4.9 \mathrm{~cm}$ and the width of the foreland zone undergoing deformation due to penetrative strain was $2 \mathrm{~cm}$.

Model 2 (Fig. 3B) was shortened $3.2 \mathrm{~cm}$ to a total shortening of $7.3 \%$. One anticline (i) formed, with an adjacent syncline. Another anticline was initiating (ii). Anticline (i) is slightly asymmetric, and silicon has been pushed into the space under the fold, creating a silicon-cored fold similar to those shown in Figure 2A. The width of the fold belt was $7.8 \mathrm{~cm}$ and the width of the foreland zone was $5 \mathrm{~cm}$.

Model 3 (Fig. 3C) was shortened $4.5 \mathrm{~cm}$ to a total shortening of $10.2 \%$. A narrow anticline (i) formed, cut by a thrust fault verging to the foreland. A second thrusted anticline formed (ii), followed by a wide syncline and another narrow anticline (iii). The anticlines have a larger
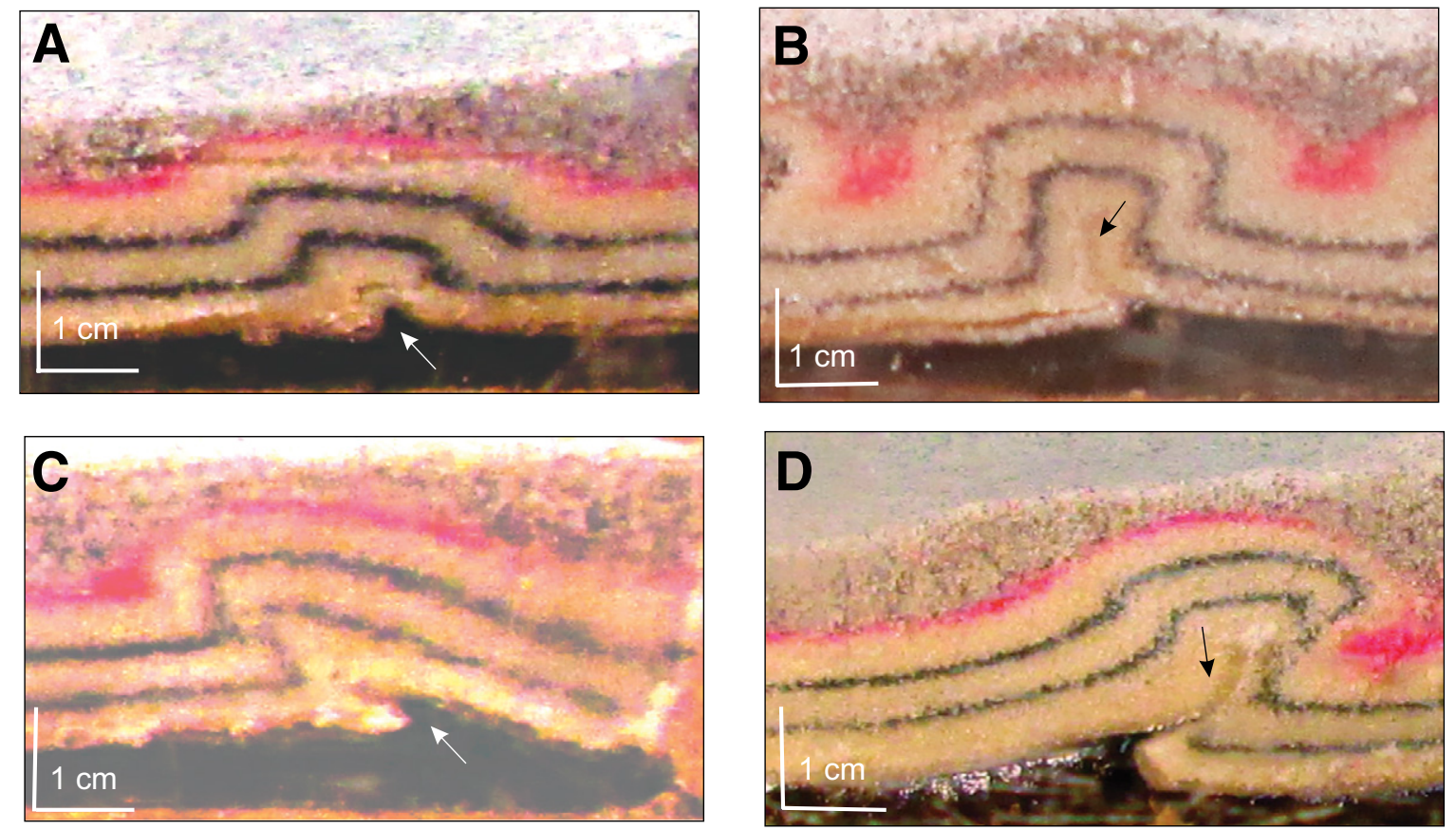

Figure 2. Examples of the four key structures found in the models. (A) Box fold with minor thickening of silicon in the core (arrow). (B) Larger amplitude box fold with thin silicon layer incorporated into the fold core (arrow). (C) Thrust and faultpropagation fold, with silicon incorporated into the thrust plane (arrow). (D) Hinterland-verging fold and thrust, with thin silicon layer associated with the thrust plane (arrow). 


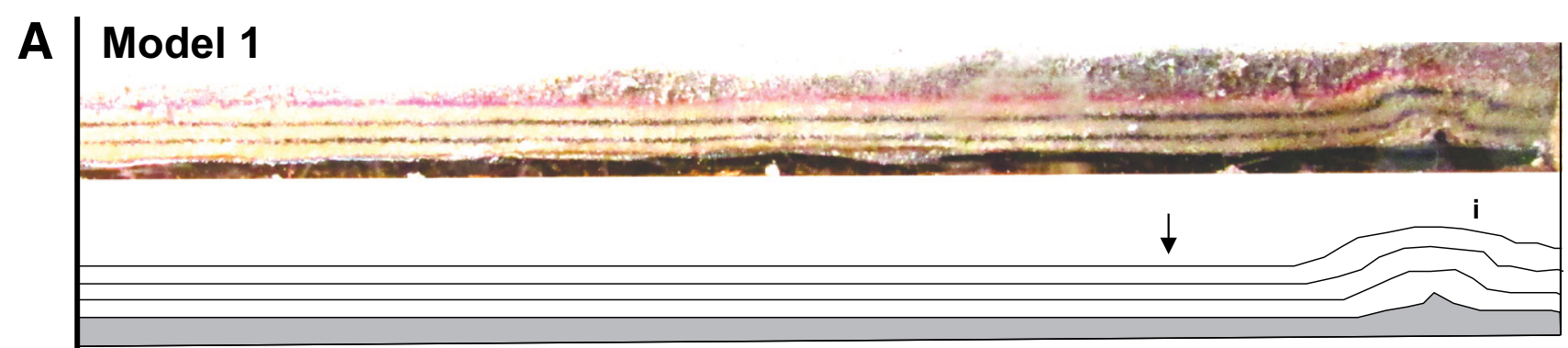

B Model 2

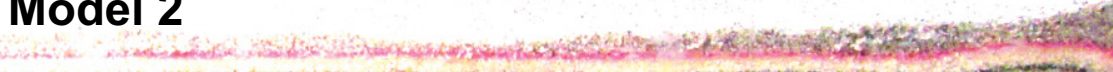
waos

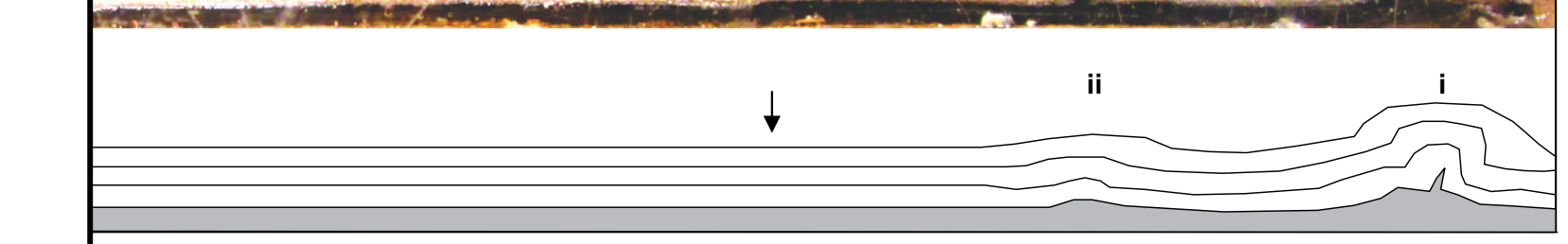

C Model 3

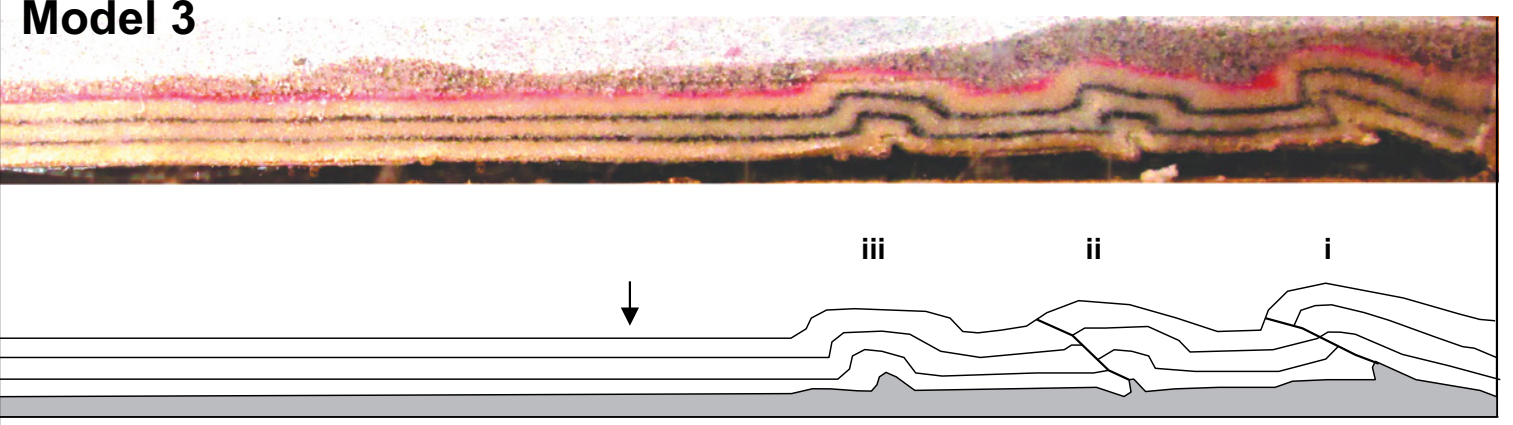

D Model 4

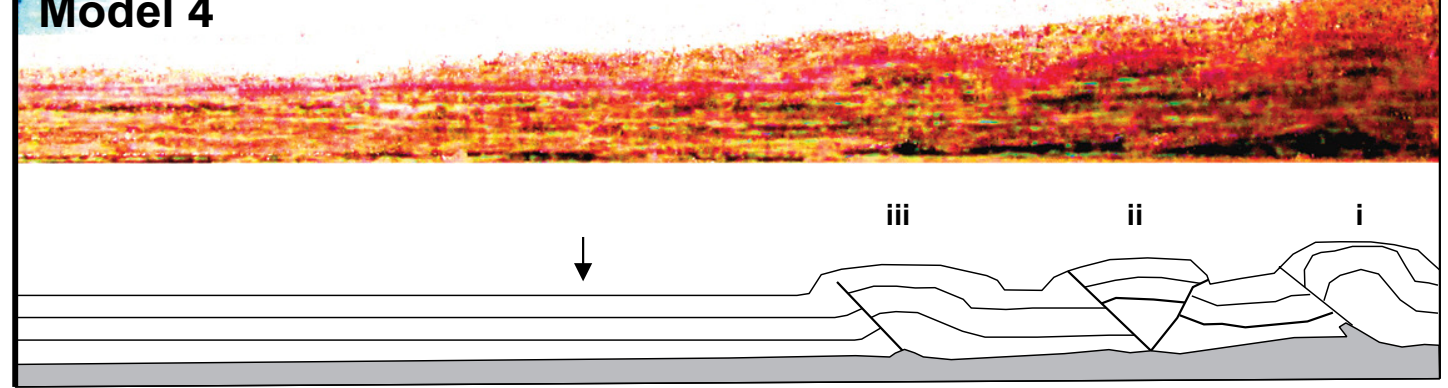

Figure 3. (A-D) Representative cross sections from models 1-4 showing both a photograph and digitized line drawing. Structures discussed in the text are labeled $\mathrm{i}$-iii. The arrow points to the end of the foreland deformation zone. 


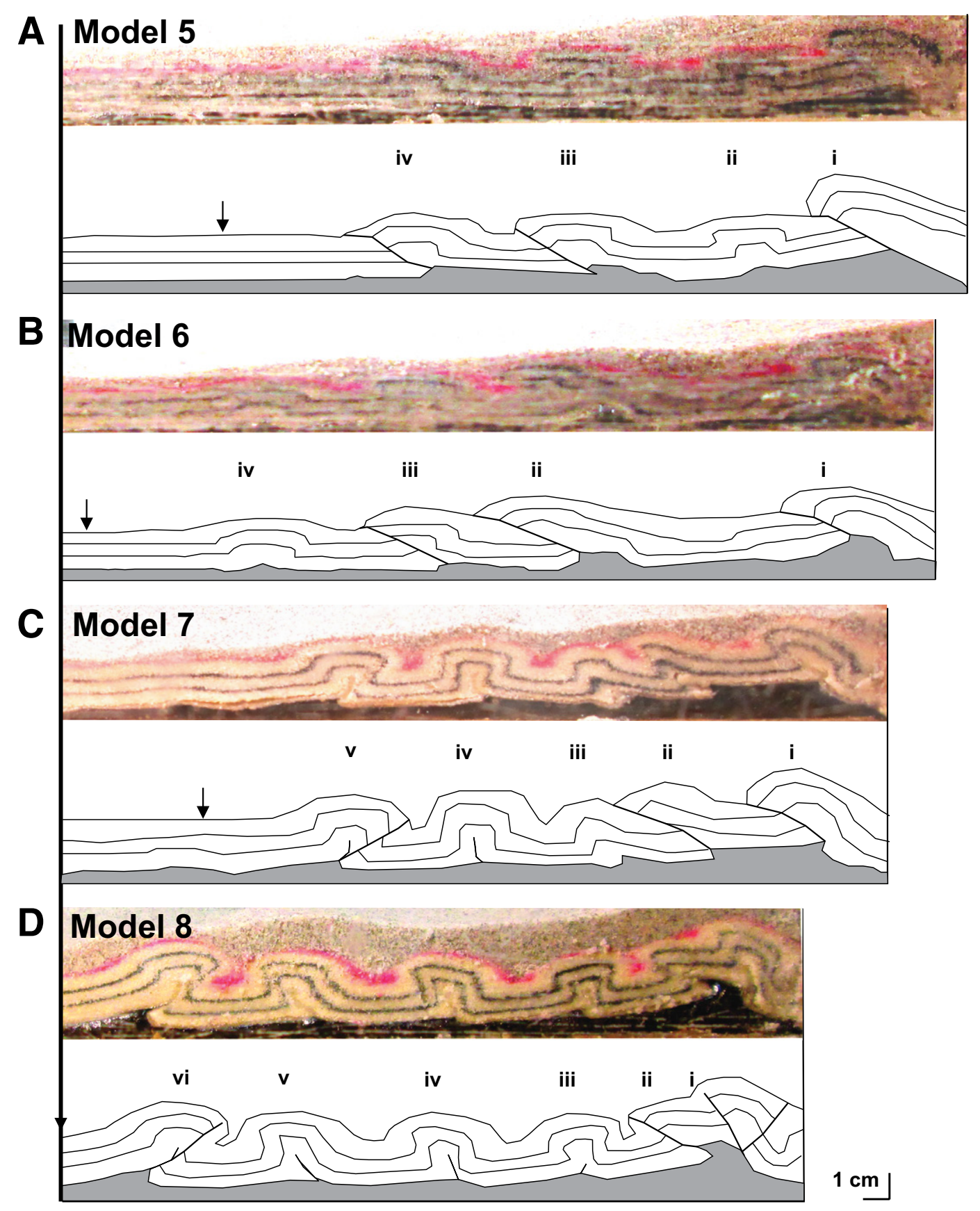

Figure 4. (A-D) Representative cross sections from models 5-8 showing both a photograph and digitized line drawing. Structures discussed in the text are labeled $i-v i$. The arrow points to the end of the foreland deformation zone. 
amplitude than in the previous model. The width of the fold belt was $13.9 \mathrm{~cm}$ and the width of the foreland zone was $3.5 \mathrm{~cm}$.

Model 4 (Fig. 3D) was shortened $6.4 \mathrm{~cm}$ to a total shortening of $14.5 \%$. There are three narrow, low-amplitude anticlines, cored by silicon, separated by two wide synclines. There are three foreland-verging thrust faults present: at the forelimb of all three anticlines present (as in models 2 and 3 ), and there is a backthrust present in anticline ii. The width of the fold belt was 14.2 $\mathrm{cm}$ and the width of the foreland zone was $5 \mathrm{~cm}$.

Model 5 (Fig. 4A) was shortened $9.6 \mathrm{~cm}$ to a total shortening of $21.8 \%$. There are four narrow anticlines separated by three wide synclines. The anticlines (ii-iv) are silicon cored (Fig. 2A) and the middle syncline (between anticline ii and iii) has thinned the silicon, restricting forward silicon flow. There are three thrust folds present: in the forelimb of the most hinterland anticline (i) and in the forelimbs of the third and fourth anticlines (iii and iv). The second anticline (ii) was not faulted. The most hinterland anticline (i) has been thrust over the first syncline with an offset of $\sim 1 \mathrm{~cm}$, similar to Figure 2C. This is a greater offset than in thrusts of previous models. The width of the fold belt was $17.1 \mathrm{~cm}$ and the width of the foreland was $4.7 \mathrm{~cm}$.

Model 6 (Fig. 4B) was shortened $10.9 \mathrm{~cm}$ to a total shortening of $24.7 \%$. There are four narrow, low-amplitude box-fold anticlines with synclines between each of them; however, the thrusting of anticline ii has overridden the adjacent syncline. All of the anticlines are silicon cored as in Figure 2A, with larger amounts of silicon under the first and third anticline ( $i$ and iii). There are three thrust faults: one thrusting the most hinterland anticline (i) over the adjacent syncline, and two more in the forelimbs of the second (ii) and third (iii) anticlines. The width of the fold belt was $20.3 \mathrm{~cm}$ and the width of the foreland was $4.1 \mathrm{~cm}$.

Model 7 (Fig. 4C) was shortened $13.4 \mathrm{~cm}$ to a total shortening of $29.1 \%$. There are five narrow box-fold anticlines with four synclines between each of them. The anticlines are silicon cored as in Figure 2B and the third syncline (between anticlines iii and iv) is thinning the silicon. There are two foreland-verging thrust faults: one thrusting the most hinterland anticline (i) over its adjacent syncline, and one in the forelimb of the third anticline (iii). A hinterlandverging thrust develops in the backlimb of the frontal anticline (v). The width of the fold belt is $17.7 \mathrm{~cm}$ and the width of the foreland is $3 \mathrm{~cm}$.

Model 8 (Fig. 4D) was shortened $16 \mathrm{~cm}$ to a total shortening of $36.4 \%$. There are six narrow box-fold anticlines with five narrow synclines between them. The anticlines are all silicon cored, and the third syncline (between anticlines iii and iv) is thinning the silicon. There are two foreland-verging thrust faults, cutting the forelimbs of the first (i) and second (ii) anticlines. Hinterland-verging thrusts develop in the backlimbs of the most hinterland anticline (i) and the frontal anticline (vi). The width of the fold belt is $22 \mathrm{~cm}$ and the width of the foreland is 4.2 $\mathrm{cm}$. Data from this model should be taken as minimum amounts, as deformation was reaching the end of the marked grid and approaching the end of the silicon base layer. It is therefore possible that we did not capture the full extent of deformation in the foreland zone.

As shortening increases, low-amplitude anticlines begin to form and silicon is thickened in the core of the fold (Fig. 2A). With increased shortening, faulting occurs in the forelimbs of the anticlines and wide synclines and narrow anticlines form in alternation. In some cases, higher amplitude anticlines develop with thin silicon cores (Fig. 2B). With increased shortening, box folds and faults continue to form, and the most hinterland fold is thrust over its adjacent syncline. The model with the greatest shortening (Fig. 4, model 8) is a classic example of box folds with foreland- and hinterland-verging thrusts over a wide thrust belt with silicon-cored anticlines and older folds being thrust on top of younger folds.

In any given model, fold belt width increases incrementally with the development of each new fold in a stepwise fashion, then belt width decreases slightly before the accommodation of a new fold (Fig. 5). The data for Figure 5 are taken from the end stages of all 8 models. The first fold begins to develop at $\sim 1.5 \%$ total shortening. A second fold begins to form at $\sim 5.8 \%$. The third fold develops at $\sim 7.3 \%$ total shortening.
A fourth fold forms at $\sim 11.6 \%$ total shortening The fifth fold begins to form at $\sim 17.4 \%$, and the sixth fold and associated backthrust began to form at $27.6 \%$ total shortening. These data allow us to define three identifiable stages of deformation in a compressive system with a ductile base layer based on how the widths of the foreland and thrust belt change (Fig. 5). During the first stage of deformation, $1 \%-10 \%$ total shortening, the system is building up the initial deformed wedge. During the second phase, $10 \%-30 \%$ total shortening, the deformation is propagating forward and the amount of shortening due to penetrative strain is significantly lower than in phase 1. During the third phase, $30 \%$ total shortening and on, backthrusts are beginning to form in the backlimb of the frontal anticline (Fig. 5).

The development of penetrative strain in the foreland was consistent throughout all 8 models; penetrative strain is greatest nearest the frontal thrust and decreases exponentially moving farther from the thrust belt. Figure 6 shows the percent of penetrative strain in relation to the width from the frontal thrust in model 8 .

The foreland zone of penetrative strain had an inverse relationship with the onset of new thrusts. In the first few stages before the first thrust forms, Figure 7A shows the accommodation of penetrative strain in the foreland from $1.5 \%$ to $4.4 \%$ total shortening. The penetrative strain was initially low and decreased with distance from the frontal thrust. As total shortening increased to $4.4 \%$, more strain was accommodated in the foreland in the same exponential decreasing fashion away from the thrust front Figure 7B shows the stages before the second thrust formed at 5.8\% total shortening. Penetrative strain is low at this stage and percentage of

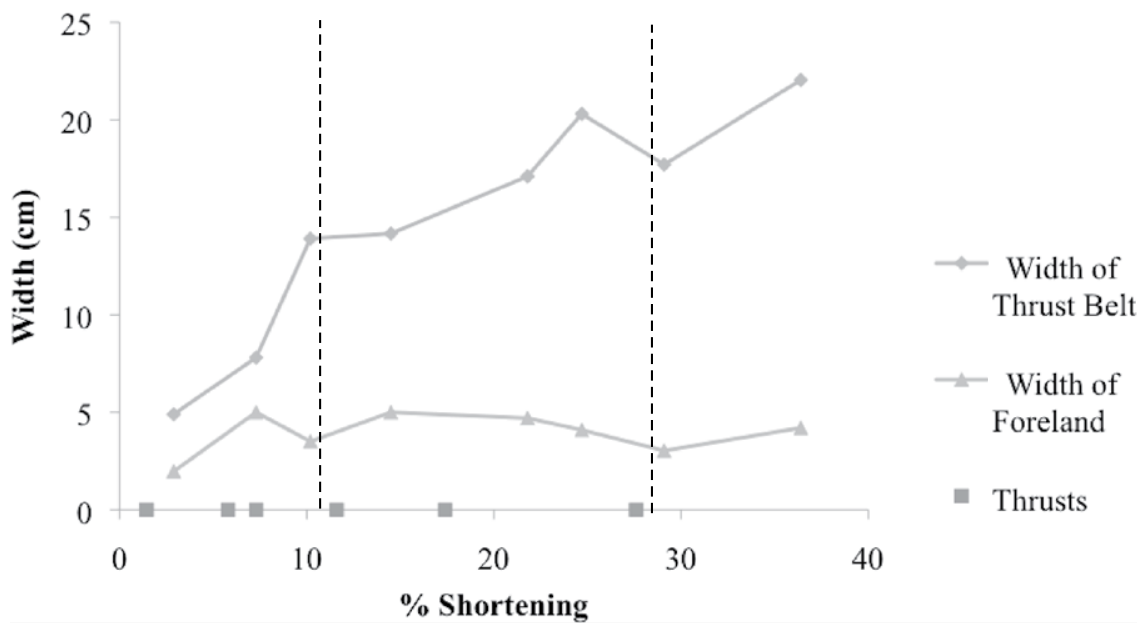

Figure 5. Progressive change in thrust belt and foreland width and throughout the deformation sequence. Squares indicate the shortening increments in which new thrusts initiated. The vertical dashed lines indicate three stages of deformation: building up of the initial deformation, propagation forward, and the formation of backthrusts. 


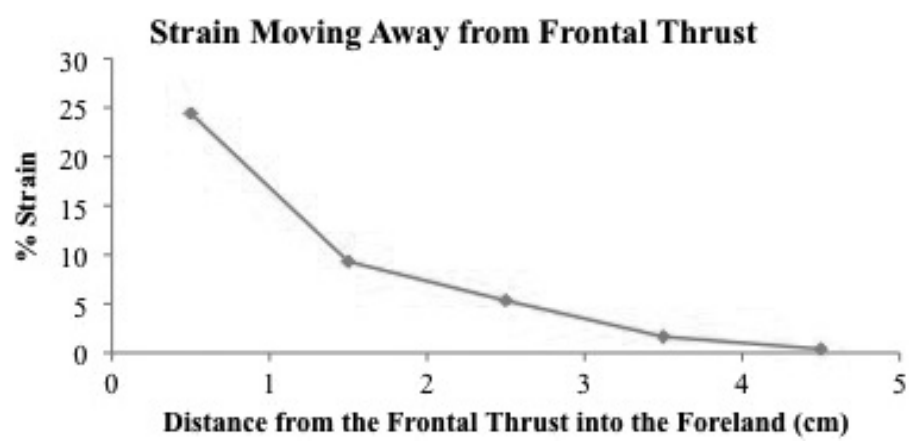

Figure 6. Representative data from model 8 , indicating the change in penetrative strain amount with increasing distance from the fold belt. Penetrative strain decreases exponentially away from the fold belt.

A

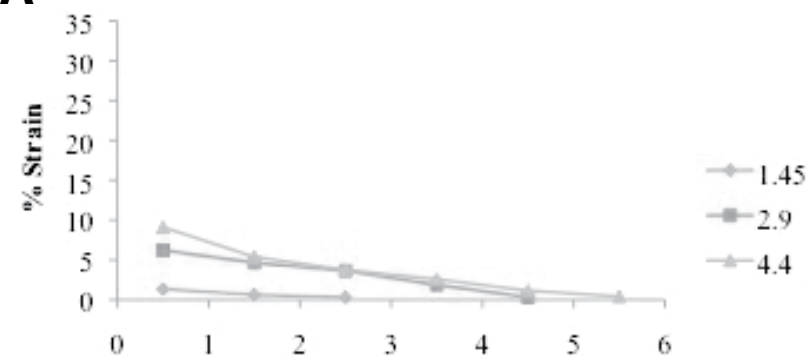

Distance from the Frontal Thrust into Foreland (cm)

C

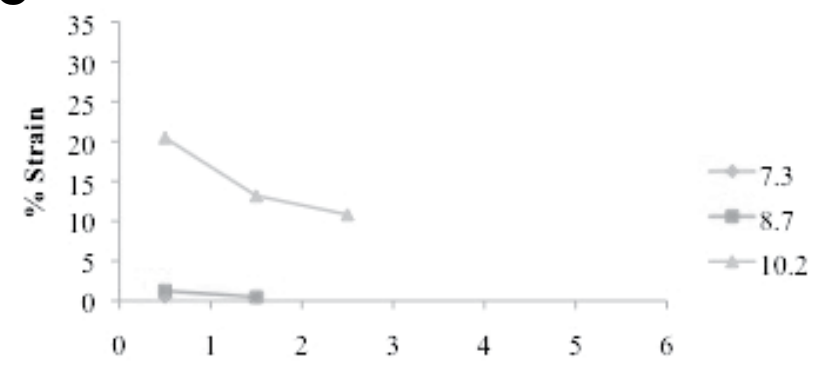

Distance from the Frontal Thrust into Foreland (cm)

E

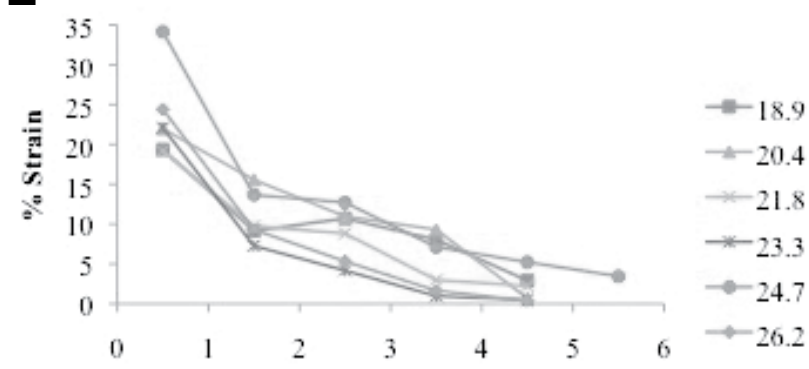

Distance from the Frontal Thrust into Foreland (cm)
B

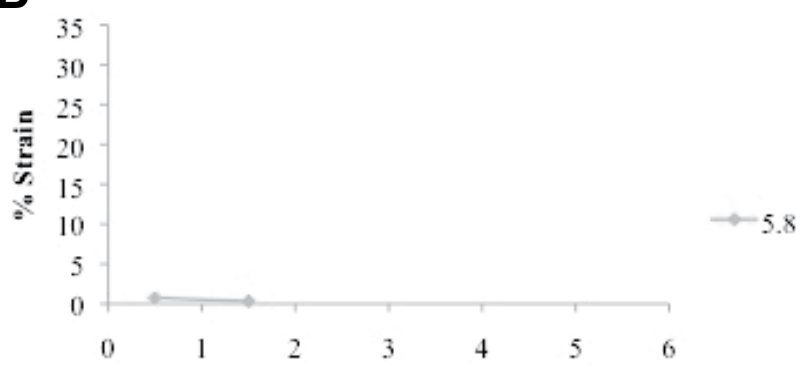

Distance from the Frontal Thrust into Foreland (cm)

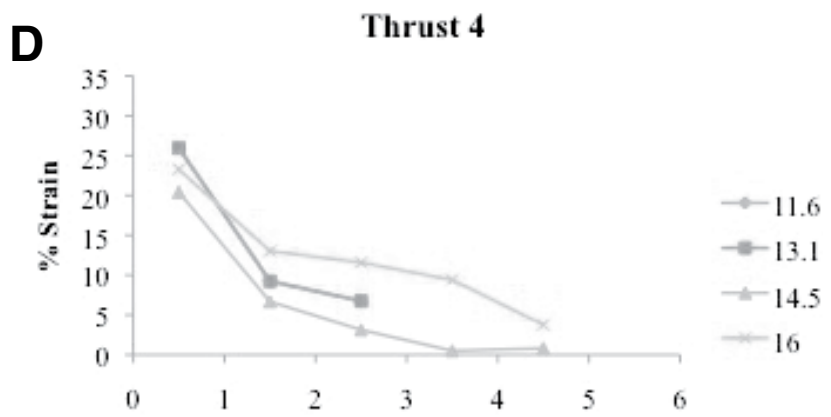

Distance from the Frontal Thrust into Foreland (cm)

F

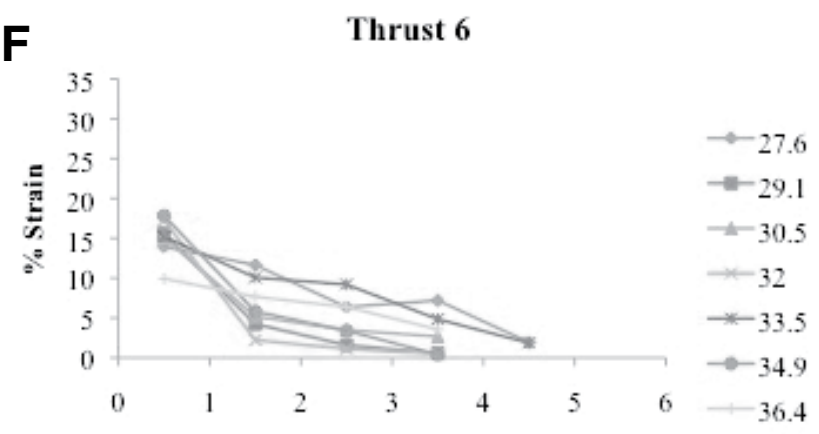

Distance from the Frontal Thrust into Foreland (cm)

Figure 7. Incremental development of penetrative strain in the foreland in model 8 . Graphs are separated by the formation of each anticline and thrust structure. (A) Data from the first thrust shortening amounts $1.5 \%-4.4 \%$. (B) Data from the second thrust with shortening amounts at $5.8 \%$. (C) Data from the third thrust with shortening amounts 7.3\%-10.2\%. (D) Data from the forth thrust with shortening amounts $11.6 \%-16 \%$. (E) Data from the fifth thrust with shortening amounts $18.9 \%-26.2 \%$ (F) Data from sixth thrust with shortening amounts $27.6 \%-36.4 \%$. 
penetrative strain decreases moving farther from the fold belt. The stages before the formation of the third thrust (Fig. 7C) show the behavior of penetrative strain from $7.3 \%$ to $10.2 \%$ total shortening. With the initiation of the new fault, penetrative strain in the foreland started low, but rose with additional compression. The percentage of penetrative strain decreases exponentially with distance from the fold belt. The stages before the formation of the fourth thrust (Fig. 7D) show the behavior of penetrative strain between $11.6 \%$ and $16 \%$ total shortening. After the initiation of the new fault, penetrative strain in the foreland is lower. As compression continues, the strain in the foreland increased to as much as $26 \%$. The percentage of penetrative strain peaks nearest the fold belt and decreases exponentially moving away from the fold belt. The stages before the formation of the fifth thrust (Fig. 7E) show the behavior of penetrative strain from $18.9 \%$ to $26.2 \%$ total shortening. After the initiation of the fifth fault, penetrative strain drops slightly. As compression continued, the percent strain increased, reaching a high of $35 \%$ strain in the area nearest the fold belt. As the previous figures showed, the percentage of penetrative strain was the highest nearest to the fold belt and decreased exponentially moving outward. The sixth fault (Fig. 7F) shows the behavior of penetrative strain between $27.6 \%$ and $36.4 \%$ total shortening. At this stage, backthrusts are forming at the deformation front of the system and the foreland deformation zone is reaching the end of the silicon sheet.

Penetrative strain varied slightly with depth within the models (Fig. 8A). The upper and lower marker layers were used for comparison, where the upper layer is the layer $5 \mathrm{~mm}$ below the surface of the model and the lower layer is the marker $1 \mathrm{~cm}$ below the model surface. There is some variability in the proportion of penetrative strain in each model, due to the timing of the thrusting at which the calculations were taken (Table 2). Overall, penetrative strain was greater in the upper layer than in the lower layer closer to the ductile layer. Figure 8A shows the penetrative strain as a percentage of the total shortening. The contribution of penetrative strain to the deformation decreases with increased deformation (i.e., the penetrative strain as a percentage of the total decreases). However, in total, the total amount of penetrative strain in the models increases through the deformation sequence but less rapidly than the tectonic shortening increases (Fig. 8B).

In summary, the amount of penetrative strain in the foreland is highest near the fold belt and decreases outward. The largest amounts of penetrative strain are accommodated in highly compressed models just before the initiation of a new fold, when penetrative strain drops in the
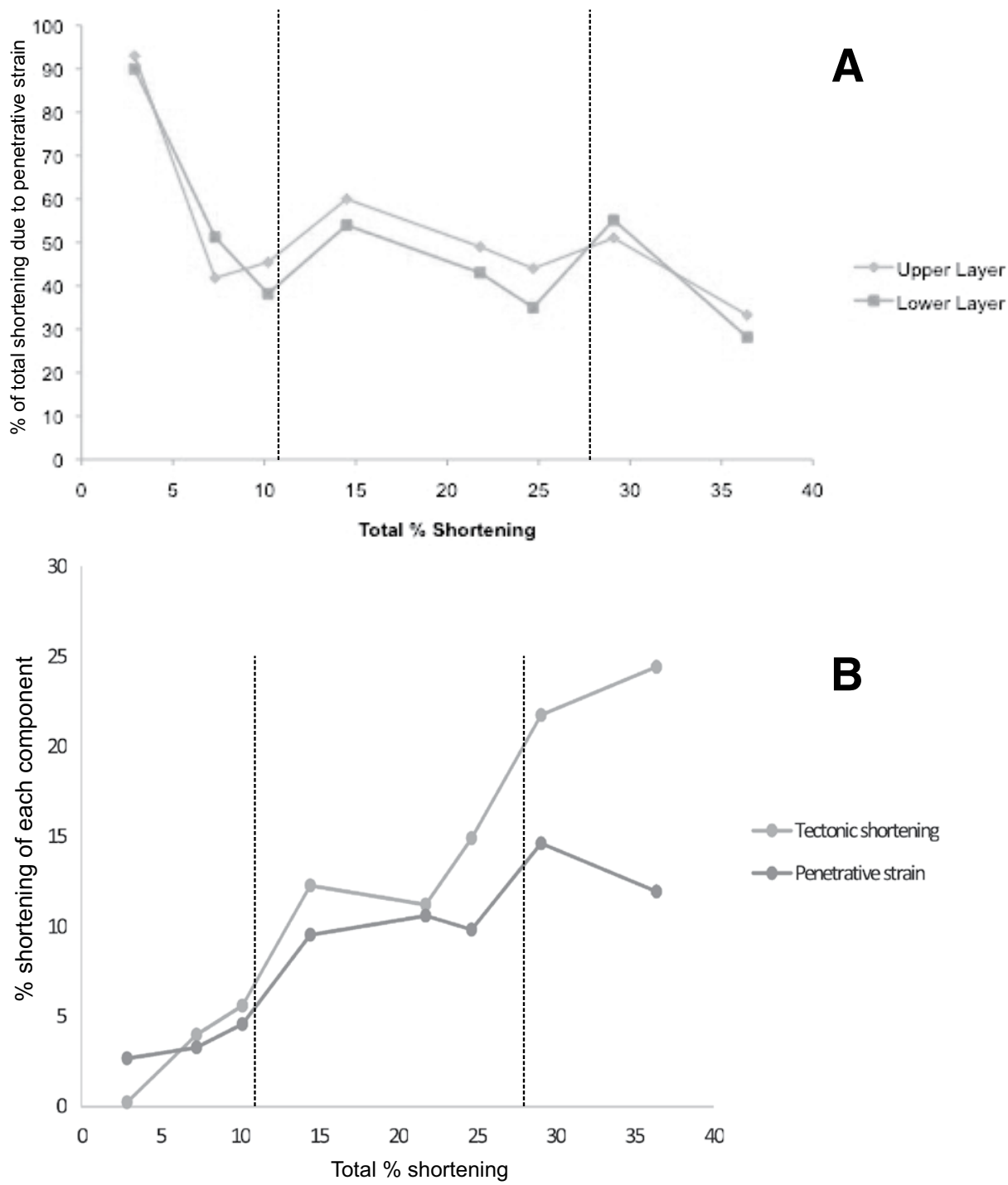

Figure 8. Shortening accommodated by penetrative strain in each model. (A) Penetrative strain in upper and lower layers as a percentage of the total shortening. The lower layer represents the marker layer closest to the silicon and upper layer represents the marker layer closest to the surface. (B)The shortening due to penetrative strain in each model (lower line) compared to the tectonic shortening in each model (upper line; continuously increasing). Vertical lines mark the different deformation stages (see discussion in text). The contribution of penetrative strain to the deformation decreases within each deformation stage.

foreland as a new weakly deformed foreland area is created. The amount of penetrative strain varies throughout the stages of deformation in a system with a ductile base layer. It can range between $30.8 \%$ and $91.5 \%$ of the total shortening, that is, $2.7 \%-14.6 \%$ shortening. This could account for a significant amount of missing shortening.

\section{IMPLICATIONS FOR NATURALTHIN-SKIN TECTONICS}

The folded external zone of the Swiss Jura is considered as an analog for the models produced

\begin{tabular}{|c|c|c|}
\hline Model & $\begin{array}{c}\text { Total } \\
\text { shortening } \\
(\%)\end{array}$ & $\begin{array}{c}\text { Shortening due to } \\
\text { penetrative strain } \\
(\%)\end{array}$ \\
\hline 1 & 2.9 & 91.5 \\
\hline 2 & 7.3 & 46.5 \\
\hline 3 & 10.2 & 41.8 \\
\hline 4 & 14.5 & 57 \\
\hline 5 & 21.8 & 46 \\
\hline 6 & 24.7 & 39.5 \\
\hline 7 & 29.1 & 46.9 \\
\hline 8 & 36.4 & 30.8 \\
\hline
\end{tabular}


in this study. This region was chosen as a comparison, as similar structures are produced in the models as are depicted in cross sections (e.g., Fig. 9) and the region can be described as the frontal region of a fold-thrust belt over a salt décollement. Sommaruga (1999) described the external Jura as a thin-skinned fold belt deformed over a weak décollement, forming low-amplitude folds cored by salt pillows. This interpretation was corroborated by Pfiffner et al. (1997) and Burkhard and Sommaruga (1998). Laubscher (1975) noted evidence of pressure solution in post-salt units, but considered the net amount of pressure solution to be negligible in this system. Ruh et al. (2012) presented a cross section of the Faltenjura, the folded external zone of the Jura (Switzerland). This section is redrawn in Figure 9. Restoring this cross section, using an average salt thickness of $165 \mathrm{~m}$ and maintaining the salt cross-sectional area, gives 11.4 $\mathrm{km}$ of tectonic shortening. The deformed area restores to an original length of $\sim 46.8 \mathrm{~km}$, which is equivalent to $24 \%$ total shortening. Following the statements of Rowan and Ratliff (2012) concerning restoration over salt layers, this restoration assumes plane strain and no salt dissolution. In accordance with the findings from Rowan and Ratliff (2012), we note that there is no extrusion of the salt, and thus consider that maintaining the area of the salt layer is reasonable.

According to this study, penetrative strain could account for a significant amount of shortening in this system (Fig. 9). The amount of penetrative strain from model 6 in this study $(24.7 \%$ total shortening, $40 \%$ of which was due to penetrative strain) was used to calculate a significant amount of shortening not accounted for in a restoration of the cross section. The calculated $11.4 \mathrm{~km}$ tectonic shortening represents $60 \%$ of the total shortening; thus penetrative strain can account for $7.6 \mathrm{~km}$ additional shortening. This brings the total shortening in the region to 19.0 $\mathrm{km}$ shortening and represents an original length of $\sim 54.4 \mathrm{~km}$.

\section{DISCUSSION}

The data from this study show that penetrative strain is present in all stages of deformation, and is not merely an early event of deformation (Dean et al., 1988; Weil and Yonkee, 2009). We find that penetrative strain is greatest in the uppermost layers and decreases with depth. Our measurements are discrete measurements in the marker layers, but we speculate that penetrative strain decreases from the uppermost layers in a smooth fashion to be zero in the incompressible silicon (i.e., salt) layer. We further find a zone of deformation to the foreland of the fold-thrust belt, within which deformation decays away to zero, compatible with the findings of Craddock and Van der Pluijm (1989).

The results from this study were compared with the results from a similar study without a ductile base layer (Fig. 10). Penetrative strain accounting for as much as $45 \%$ of the total shortening (i.e., a maximum penetrative strain of 4.9\%) was reported in Burberry (2015), who also reported trends of penetrative strain increasing with depth and increased total shortening decreasing the contribution of penetrative strain. Our study is fundamentally different from the brittle system measured in Burberry (2015). Systems with a ductile base layer behave very differently from purely brittle systems, as is known from Dahlen et al. (1984) and as discussed in the Introduction herein. Brittle structures tend to form one deformed wedge with a series of thrust faults, while salt-underlain systems tend to form rolling box folds.

The data collected from Burberry (2015) were interpreted as this study was, with the 20 $\mathrm{cm}$ of undeformed model removed from calculations to better replicate a natural system. There is significantly more penetrative strain in every stage of deformation in a brittle system with a ductile base layer than in a purely brittle system. This may be because there are fewer faults in a system with a salt décollement. There is less translation due to faulting, so more deformation must be accounted for by penetrative strain.

In Burberry (2015) penetrative strain accounted for $3.6 \%-45.2 \%$ of total shortening (i.e., $0.9 \%-4.9 \%$ shortening), while in this study, penetrative strain accounts for between $30.8 \%$ and $91.5 \%$ of total shortening (i.e., $2.7 \%-14.6 \%$ shortening), depending on the stage of deformation (Fig. 10). There is a much higher degree of penetrative strain in systems with a salt décollement, but there are some similarities. For example, in the foreland strain zone of both systems, penetrative strain (1) is higher closest to the fold belt and decreases as it propagates outward, and (2) drops after the formation of a new thrust and then increases until the accommodation of a new fault. Penetrative strain increased with depth in every model of the brittle systems. In models with a ductile décollement, penetrative strain decreased with depth in 6 of the 10 models. If this is indicative of penetrative strain decreasing with depth, we speculate that penetrative strain is a continuum, being highest at the top of the sedimentary pile and near zero directly adjacent to the incompressible silicon.

Our results, however, differ from those of Koyi et al. (2004); their findings also showed a heterogeneous penetrative strain in time and space, but that the penetrative strain increased with depth in the sand pack over a ductile décollement, and varied with thickness of the silicon layer. We suggest that this variation is due to the difference in setup between the model suites, with the Koyi et al. (2004) experiments
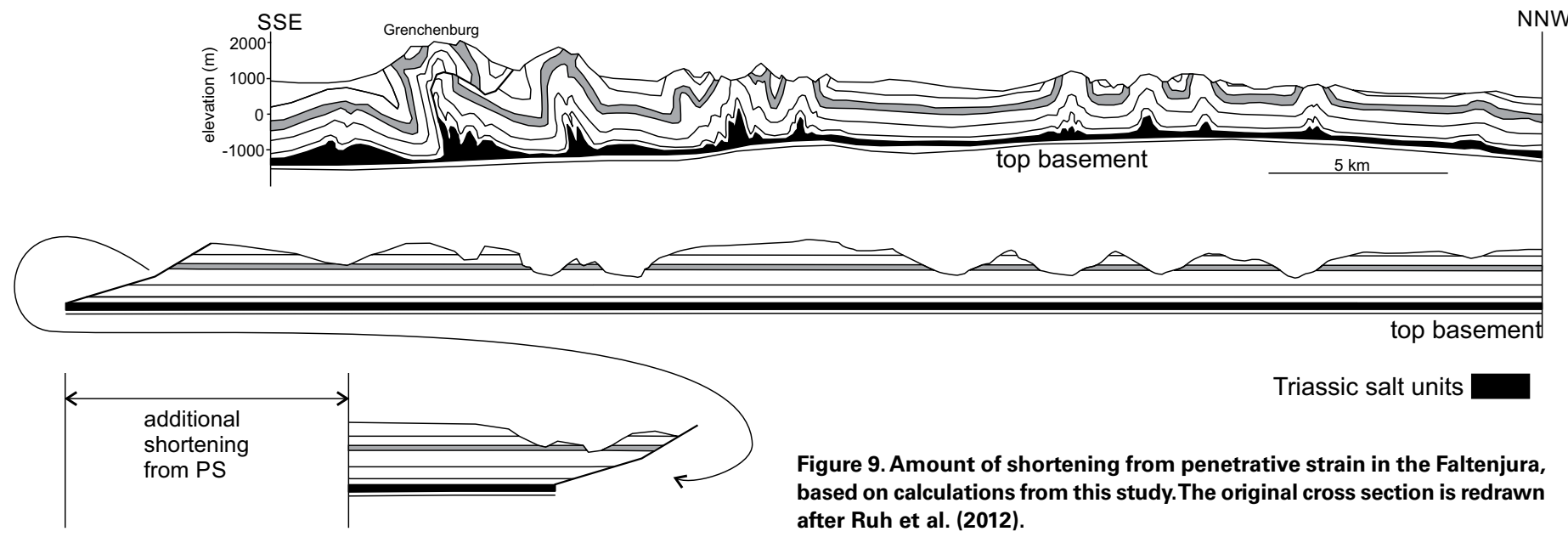
based on calculations from this study. The original cross section is redrawn after Ruh et al. (2012). 

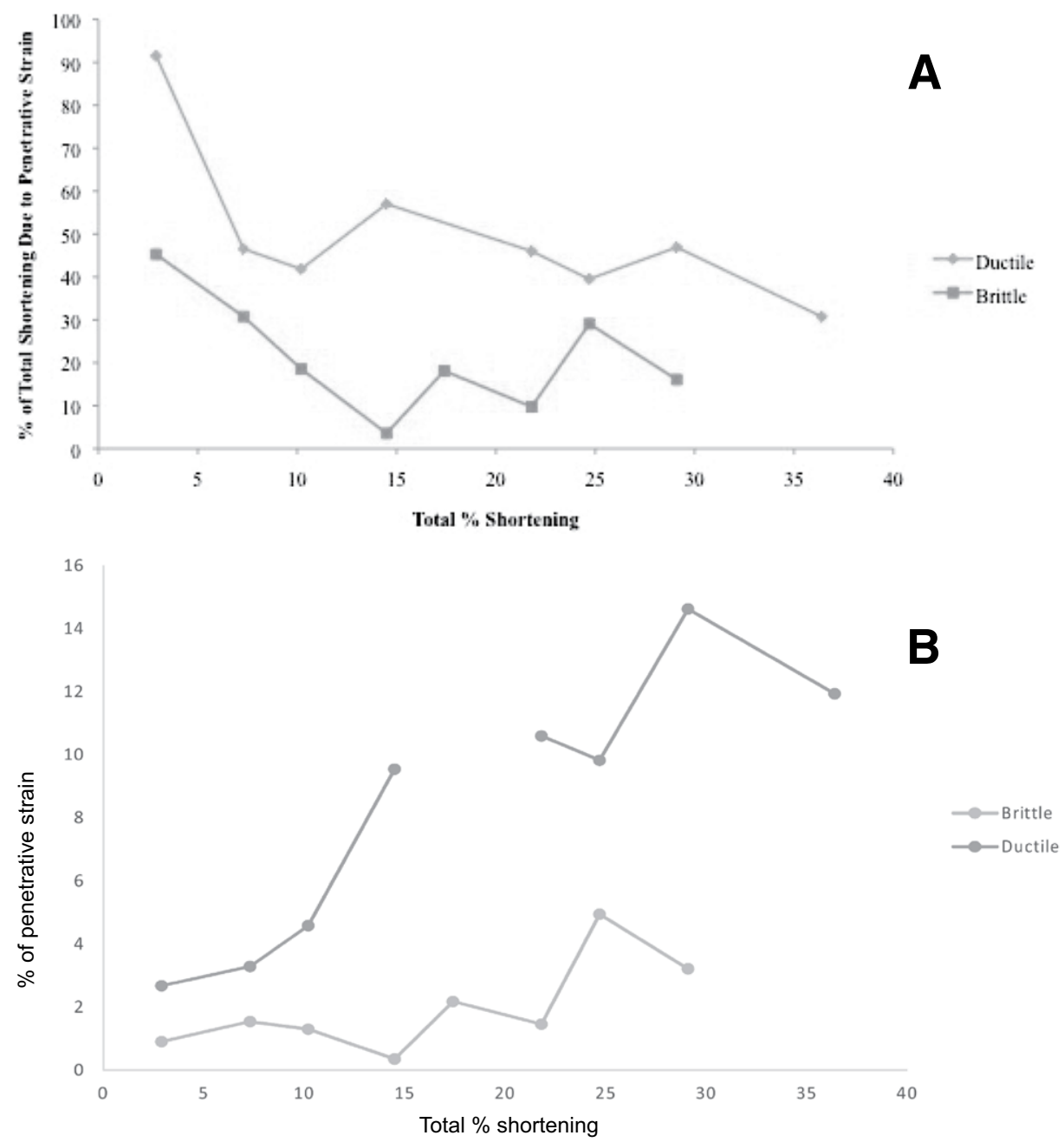

Figure 10. Comparison of penetrative strain (PS) data from this study and Burberry (2015). (A) A comparison of penetrative strain displayed as a percentage of the total shortening. (B) Absolute penetrative strain amounts in each series of models. In both cases, the data indicate that the sand pack above the ductile décollement accommodates significantly more penetrative strain than the sand pack above the brittle décollement.

containing a different sand/silicon ratio and containing a pinch-out of the silicon layer, analogous to the situation in the Pyrenees. A valuable contribution to future work would be to investigate the effects of varying thicknesses of the salt/silicon layer on the structures formed; this could be achieved with a suite of models with systematically varying salt/overburden ratios.

\section{CONCLUSIONS}

The eight analog models presented in this study have demonstrated that (1) brittle systems over a ductile décollement form box-fold structures; (2) penetrative strain is present at every stage of deformation, as some amount of penetrative strain was observed in every model; (3) penetrative strain in the foreland increases before the initiation of a new fault and decreases abruptly after a new fault has formed and a new region becomes the foreland; (4) penetrative strain in the foreland is greatest nearest the thrust belt and decreases moving away from the belt; (5) penetrative strain in the brittle units may decrease with depth; and (6) penetrative strain can account for a significant proportion of total shortening in brittle systems with a ductile décollement depending on the timing, with values ranging between $91.5 \%$ in less deformed models to $30.8 \%$ in more deformed models. Expressed as absolute values, penetrative strain ranges from $2.7 \%$ to $14.6 \%$ shortening.

Few studies have incorporated penetrative strain into restorations of salt-floored belts. The example from the Faltenjura presented here indicates that estimates from this study could help better calculate the true total shortening of an orogen and help resolve the problem of missing shortening.

\section{ACKNOWLEDGMENTS}

We thank research assistant Claire Richardson for help with running the models in this series, and Midland Valley Ltd. for an academic license for the MOVE software. We are also grateful for constructive comments from J. Reber and D. McCarthy, whose time and effort greatly improved this manuscript.

\section{REFERENCES CITED}

Agard, P., Omrani, J., Jolivet, L., and Mouthereau, F., 2005 Convergence history across Zagros (Iran): Constraints from collisional and earlier deformation: International Journal of Earth Sciences, v. 94, p. 401-419, doi:10.1007 /s00531-005-0481-4.

Bahroudi, A., and Koyi, H.A., 2003, Effect of spatial distribution of Hormuz Salt on deformation style in the Zagros fold and thrust belt: An analogue modeling approach: Journal of the Geological Society [London], v. 160, p. 719733, doi:10.1144/0016-764902-135.

Bonini, M., 2003, Detachment folding, fold amplification, and diapirism in thrust wedge experiments: Tectonics, v. 22 1065, doi:10.1029/2002TC001458.

Brun, J.P., and Fort, X., 2011, Salt tectonics at passive margins: Geology vs models: Marine and Petroleum Geology v. 28, p. 1123-1145, doi:10.1016/j.marpetgeo.2011.03.004.

Burberry, C.M., 2015, Spatial and temporal variation in penetrative strain during compression: Insights from analog models: Lithosphere, v. 6, p. 611-624, doi:10.1130/1454.1.

Burkhard, M., and Sommaruga, A., 1998, Evolution of the Western Swiss Molasse Basin: Structural relations with the Alps and the Jura belt, in Mascle, A., et al., eds., Cenozoic foreland basins of western Europe: Geological Society, London, Special Publication 134, p. 279-298, doi: 10.1144/GSL.SP.1998.134.01.13.

Costa, E., and Venderville, E.C., 2002, Experimental insights on the geometry and kinematics of fold-and-thrust belts above weak, viscous evaporitic décollement: Journal of Structural Geology, v. 24, p. 1729-1739, doi:10.1016 /S0191-8141(01)00169-9.

Cotton, J.T., and Koyi, H.A., 2000, Modeling of thrust fronts above ductile and frictional detachments: Application to structures in the Salt Range and Potwar Plateau, Pakistan: Geological Society of America Bulletin, v. 112, p. 351-363, doi:10.1130/0016-7606(2000)112<351:MOTFAD>2.0.CO;2.

Couzens, B.A., Dunne, W.M., Onasch, C.M., and Glass, R. 1993, Strain variations and three-dimensional strain factorization at the transition from the southern to the central Appalachians: Journal of Structural Geology, v. 15 p. 451-464, doi:10.1016/0191-8141(93)90140-6.

Craddock, J.P., and Van der Pluijm, B.A., 1989, Late Paleozoic deformation of the cratonic carbonate cover of eastern North America: Geology, v. 17, p. 416-419, doi:10.1130 /0091-7613(1989)017<0416:LPDOTC>2.3.CO;2.

Dahlen, F.A., Suppe, J., and Davis, D., 1984, Mechanics of fold-and-thrust belts and accretionary wedges: Cohesive Coulomb theory: Journal of Geophysical Research, v. 89, p. 10,087-10,101, doi:10.1029/JB089iB12p10087.

Davis, D.M., and Engelder, T., 1985, The role of salt in fold-andthrust belts:Tectonophysics, v. 119, p. 67-88, doi:10.1016 /0040-1951(85)90033-2.

Dean, S.L., Kulander, B.R., and Skinner, J.M., 1988, Structural chronology of the Alleghanian orogeny in southeastern West Virginia: Geological Society of America Bulletin, v. 100, p. 299-310, doi:10.1130/0016-7606(1988) 100<0299: SCOTAO $>2.3 . C O ; 2$.

Dooley, T., McClay, K.R., Hempton, M., and Smit, D., 2005, Salt tectonics above complex basement extensional fault systems: Results from analogue modelling, in Doré , A.G. and Vining, B.A., eds., Petroleum geology: North-west Europe and global perspectives-Proceedings of the 6th Petroleum Geology Conference: Geological Society of London Petroleum Geology Conference Series 2005, v. 6, p. 1631-1648, doi:10.1144/0061631.

Engelder, T., and Engelder, R., 1977, Fossil distortion and décollement tectonics of the Appalachian Plateau: Geology, v. 5, p. 457-460, doi:10.1130/0091-7613(1977)5<457: FDADTO>2.0.CO;2. 
Epard, J.L., and Groshong, R.H., Jr., 1995, Kinematic model of detachment folding including limb rotation, fixed hinges and layer-parallel strain:Tectonophysics, v. 247, p. 85-103, doi:10.1016/0040-1951(94)00266-C.

Fischer, M.W., and Coward, M.P., 1982, Strains and folds within thrust sheets: An analysis of the Heilam Sheet, NW Scotland:Tectonophysics, v. 88, p. 291-312, doi:10 1016/0040-1951(82)90241-4.

Geiser, P., and Engelder, T., 1983, The distribution of layer parallel shortening fabrics in the Appalachian foreland of NewYork and Pennsylvania: Evidence for two non-coaxial phases of the Alleghanian orogeny, in Hatcher, R.D., Jr., et al., eds., Contributions to the tectonics and geophysics of mountain chains: Geological Society of America Memoir 158, p. 161-176, doi:10.1130/MEM158-p161.

Gray, M.B., and Mitra, G., 1993, Migration of deformation fronts during progressive deformation: Evidence from detailed structural studies in the Pennsylvania anthracite region, USA: Journal of Structural Geology, v. 15, p. 435-449, doi:10.1016/0191-8141(93)90139-2.

Groshong, R.H., Jr., 1975, Strain, fractures and pressure solution in natural single-layer folds: Geological Society of America Bulletin, v. 86, p. 1363-1376, doi:10.1130/0016 -7606(1975)86<1363:SFAPSI>2.0.CO;2.

Guillot, S., Garzanti, E., Baratoux, D., Marquer, D., Maheo, G., and de Sigoyer, J., 2003, Reconstructing the total shortening history of the NW Himalaya: Geochemistry, Geophysics, Geosystems, v. 4, 1064, doi:10.1029 /2002GC000484.

Henderson, J.R., Wright, T.O., and Henderson, M.N., 1986, A history of cleavage and folding: An example from the Goldenville Formation, Nova Scotia: Geological Society of America Bulletin, v. 97, p. 1354-1366, doi:10.1130/0016 7606(1986)97<1354:AHOCAF>2.0.CO;2.

Hessami, K., Nilforoushan, F., and Talbot, C.J., 2006, Active deformation within the Zagros Mountains deduced from GPS measurements: Journal of the Geological Society [London], v. 163, p. 143-148, doi:10.1144/0016-764905-031.

Hogan, J.P., and Dunne, W.M., 2001, Calculation of shortening due to outcrop-scale deformation and its relation to regional deformation patterns: Journal of Structural Geology, v. 23, p. 1507-1529, doi:10.1016/S0191-8141(01) 00016-5.

Hubbert, M.K., 1937, Theory of scale models as applied to the study of geologic structures: Geological Society of America Bulletin, v. 48, p. 1459-1520, doi:10.1130/GSAB 48-1459.

Hudec, M.R., and Jackson, M.P.A., 2007, Terra inferma: Understanding salt tectonics: Earth-Science Reviews, v. 82, p. 1-28, doi:10.1016/j.earscirev.2007.01.001.

Jackson, M.P.A., and Talbot, C.J., 1991, A glossary of salt tectonics: University ofTexas at Austin Bureau of Economic Geology Geological Circular 91, 44 p.

Jaumé, S.C., and Lillie, R.J., 1988, Mechanics of the Salt Range-Potwar Plateau, Pakistan: A fold-and-thrust belt underlain by evaporates: Tectonics, v. 7, p. 57-71, doi: 10.1029/TC007i001p00057.

Judge, P.A., and Allmendinger, R.W., 2011, Assessing uncertainties in balanced cross-sections: Journal of Structural Geology, v. 33, p. 458-467, doi:10.1016/j.jsg.2011.01.006.

Johnson, A., 1980, Folding and faulting of strain-hardening sedimentary rocks:Tectonophysics, v. 62 , p. 251-278, doi: 10.1016/0040-1951(80)90196-1.

Konstantinovskaya, E., and Malavieille, J., 2011, Thrust wedges with décollement levels and syntectonic erosion: A view from analog models:Tectonophysics, v. 502, p. 336-350, doi:10.1016/j.tecto.2011.01.020.
Koyi, H.A., 1995, Mode of internal deformation in sand wedges: Journal of Structural Geology, v. 17, p. 293-300 doi:10.1016/0191-8141(94)00050-A.

Koyi, H.A., Sans, M.T., Cotton, J., and Zeyen, H., 2004, The significance of penetrative strain in the restoration of shortened layers-Insights from sand models and the Spanish Pyrenees, in McClay, K.R., ed., Thrust tectonics and hydrocarbon systems: American Association of $\mathrm{Pe}-$ troleum Geologists Memoir 82, p. 1-16.

Krantz, R.W., 1991, Measurements of friction coefficients and cohesion for faulting and fault reactivation in laboratory models using sand and sand mixtures: Tectonophysics, v. 188, p. 203-207, doi:10.1016/0040-1951(91)90323-K.

Laubscher, H.P., 1975, Viscous components in Jura folding: Tectonophysics, v. 27, p. 239-254/

Letouzey, J., Colletta, B., Vially, R., and Chermette, J.C., 1995 Evolution of salt-related structures in compressional settings, in Jackson, M.P.A., et al., eds., Salt tectonics, a global perspective: American Association of Petroleum Geologists Memoir 65, p. 41-60.

Masini, M., Poblet, J., and Bulnes, M., 2010, Cross-section restoration: A tool to simulate deformation. Application to a fault-propagation fold from the Cantabrian fold and thrust belt, NW Iberian Peninsula: Journal of Structural Geology, v. 32, p. 172-183, doi:10.1016/j.jsg.2009.11.002.

Meere, P.A., Mulchrone, K.F., Sears, J.W., and Bradway, M.D. 2008 , The effect of non-passive clast behaviour in the estimation of finite strain in sedimentary rocks: Journal of Structural Geology, v. 30, p. 1264-1271, doi:10.1016 /j.jsg.2008.06.008.

Meere, P.A., Mulchrone, K.F., McCarthy, D.J., Timmerman, M.J., and Dewey, J.F., 2016, Prelithification and synlithification tectonic foliation development in a clastic sedimentary sequence: Geology, v. 44, p. 291-294, doi: 10.1130/G37587.1.

McQuarrie, N., 2004, Crustal scale geometry of the Zagros fold-thrust belt, Iran: Journal of Structural Geology, v. 26 , p. 519-535, doi:10.1016/j.jsg.2003.08.009.

Mitra, G., 1994, Strain variation in thrust sheets across the Sevier fold-and-thrust belt (Idaho-Utah-Wyoming): Implications for section restoration and wedge taper evolution: Journal of Structural Geology, v. 16, p. 585-602, doi:10.1016/0191-8141(94)90099-X.

Moretti, I., and Callot, J.-P., 2012, Area, length and thickness conservation: Dogma or reality?: Journal of Structural Geology, v. 41, p. 64-75, doi:10.1016/j.jsg.2012.02.014.

Mouthereau, F., Lacombe, O., and Verges, J., 2012, Building the Zagros collisional orogen:Timing, strain distribution and the dynamics of Arabia/Eurasia plate convergence:Tectonophysics, v. 532-535, p. 27-60, doi:10.1016 /j.tecto.2012.01.022.

Nilforoushan, F., et al., 2003, GPS network monitors the Arabia-Eurasia collision deformation in Iran: Journal of Geodesy, v. 77, p. 411-422, doi:10.1007/s00190-003-0326-5.

Onasch, C.M., 1993, Determination of pressure solution shortening in sandstones: Tectonophysics, v. 227, p. 145-159, doi:10.1016/0040-1951(93)90092-X

Pennock, E.S., Lillie, R.J., Zaman, A.S.H., andYousaf, M., 1989 Structural interpretation of seismic reflection data from eastern Salt Range and Potwar Plateau, Pakistan: American Association of Petroleum Geologists Bulletin, v. 73, p. 841-857.

Pfiffner, O.A., Erard, P.F., and Stäuble, M., 1997, Two cross sections through the Swiss Molasse Basin (lines E4-E6, W1, W7-W10), in Pfiffner, O., et al., eds., Deep structure of the Swiss Alps. Results of NRP 20: Basel, Birkhäuser Verlag, p. 64-72.
Popov, V.G., 2000, Lithological and hydrogeochemical role of the density convection in sedimentation basins with halogenous formations: Lithology and Mineral Resources v. 35, p. 365-372, doi:10.1007/BF02782692.

Qayyum, M., Spratt, D.A., Dixon, J.M., and Lawrence, R.D. 2015, Displacement transfer from fault-bend to faultpropagation fold geometry: An example from the Himalayan thrust front: Journal of Structural Geology, v. 77, p. 260-276, doi:10.1016/j.jsg.2014.10.010.

Rowan, M.G., and Ratliff, R.A., 2012, Cross-section restoration of salt-related deformation: Best practices and potentia pitfalls: Journal of Structural Geology, v. 41, p. 24-37, doi: 10.1016/j.jsg.2011.12.012.

Ruh, J.B., Kaus, B.J.P., and Burg, J., 2012, Numerical investigation of deformation mechanics in fold-and-thrust belts: Influence of rheology of single and multiple décollements: Tectonics, v. 31,TC3005, doi:10.1029/2011TC003047.

Sans, M., Vergés, J., Gomis, E., Parés, J.M., Schiattarella, M., Travé, A., Calvet, F., Santanach, P., and Doulcet, A., 2003, Layer parallel shortening in salt-detached folds: Constraint on cross-section restoration: Tectonophysics, v. 372, p. 85-104, doi:10.1016/S0040-1951(03)00233-6.

Sommaruga, A., 1999, Decollement tectonics in the Jura foreland fold-and-thrust belt: Marine and Petroleum Geol ogy, v. 16, p. 111-134, doi:10.1016/S0264-8172(98)00068-3

Tavarnelli, E., 1997, Structural evolution of a foreland foldthrust belt: The Umbria-Marche Apennines, Italy: Journal of Structural Geology, v. 19, p. 523-534, doi:10.1016 IS0191-8141(96)00093-4.

Vernant, P., Fadil, A., Mourabit, T., Ouazar, D., Koulali, A., Davila, J.M., Garate, J., McClusky, S., and Reilinger, R., 2010, Geodetic constraints on active tectonics of the Western Mediterranean: Implications for the kinematics and dynamics of the Nubia-Eurasia plate boundary zone: Journal of Geodynamics, v. 49, p. 123-129, doi:10.1016/j.jog 2009.10.007.

Warsitzka, M., Kley, J., and Kukowski, N., 2013, Salt diapir ism driven by differential loading-Some insights from analogue modeling:Tectonophysics, v. 591, p. 83-97, doi: 10.1016/j.tecto.2011.11.018.

Weil, A.B., and Yonkee, A., 2009, Anisotropy of magnetic susceptibility in weakly deformed red beds from the Wyoming salient, Sevier thrust belt: Relations to layer-parallel shortening and orogenic curvature: Lithosphere, v. 1, p. 235-256, doi:10.1130/L42.1.

Wiltschko, D.V., Medwedeff, D.A., and Milson, H.E., 1985, Distribution and mechanisms of strain within rocks on the northwest ramp of Pine Mountain block, Southern Appalachian foreland: A field test of theory: Geological Society of America Bulletin, v. 96, p. 426-435, doi:10.1130/0016 $-7606(1985) 96<426$ :DAMOSW>2.0.CO;2.

Wojtal, S., 1989, Measuring displacement gradients and strains in faulted rocks: Journal of Structural Geology, v. 11, p. 669-678, doi:10.1016/0191-8141(89)90003-5.

Woodward, N.B., Gray, D.R., and Spears, D.B., 1986, Including strain data in balanced cross-sections: Journal of Structural Geology, v. 8, p. 313-324, doi:10.1016/0191 8141(86)90052-0.

Zhao, W., Nelson, K.D., and Project INDEPTH Team, 1993, Deep seismic reflection evidence for continental underthrusting beneath south Tibet: Nature, v. 366, p. 557-559, doi:10.1038/366557a0.

MANUSCRIPT RECEIVED 29 APRIL 2016

REVISED MANUSCRIPT RECEIVED 15 NOVEMBER 2016

MANUSCRIPT ACCEPTED 9 DECEMBER 2016

Printed in the USA 